\title{
(5)

\section{En mann i 20-årene med feber og sterke magesmerter under høyre kostalbue}

NOE Å LÆRE AV

\section{HASINA MOADDAB HØNNÅS}

E-post: hasina.moaddab.honnas@stolav.no

Revmatologisk avdeling

Ålesund sjukehus

Hasina Moaddab Hønnås er lege i spesialisering.

Forfatteren har fylt ut ICMJE-skjemaet og oppgir ingen interessekonflikter.

\section{INGRID PRYTZ BERSET}

Ålesund Mage Tarm Klinikk

og

Universitetet i Oslo

Ingrid Prytz Berset er spesialist i indremedisin, i fordøyelsessykdommer og i nyresykdommer. Hun er avtalespesialist i fordøyelsessykdommer og ph.d.-stipendiat.

Forfatteren har fylt ut ICMJE-skjemaet og oppgir ingen interessekonflikter.

\section{HARALD AARSET}

Avdeling for patologi

St. Olavs hospital

Harald Aarset er spesialist i patologi, med spesialkompetanse i nefropatologi. Han er avdelingssjef og medlem av styret for det norske nyrebiopsiregisteret.

Forfatteren har fylt ut ICMJE-skjemaet og oppgir ingen interessekonflikter.

\section{ROBERT BRUDEVOLD}

Medisinsk avdeling

Ålesund sjukehus

Robert Brudevold er spesialist i indremedisin og i hematologi og er seksjonsoverlege.

Forfatteren har fylt ut ICMJE-skjemaet og oppgir ingen interessekonflikter.

En mann i 2o-årene ble innlagt i kirurgisk avdeling etter seks dagers sykehistorie med feber og takvise smerter under høyre kostalbue. Han hadde kjent ulcerøs kolitt, og prednisolon var nedtrappet og seponert tre uker i forveien. Sykdomsforløpet ble dramatisk, og endelig diagnose var uventet.

Fra tidligere hadde pasienten hatt lettgradig atopisk eksem som barn og hadde et halvt år tidligere fått diagnostisert ulcerøs totalkolitt. Det var da blitt startet behandling med peroral mesalazin etterfulgt av peroral budesonid. Da dette behandlingsregimet ikke hadde gitt tilfredsstillende symptomlindring, hadde han fått prednisolon $40 \mathrm{mg} \times 1$ peroralt, med 
plan for nedtrapping og seponering over fire måneder. Ved innleggelsen brukte han ingen faste medisiner. Prednisolon var seponert tre uker i forveien.

I mottaket anga pasienten smerte under høyre kostalbue, men var ellers smertefri.

Blodtrykket var $147 / 80 \mathrm{~mm} \mathrm{Hg}$, pulsen $93 \mathrm{slag} / \mathrm{min}$, temperaturen $39^{\circ} \mathrm{C}$,

respirasjonsfrekvensen 20 og den perifere oksygenmetningen $99 \%$.

Bortsett fra palpasjonsømhet i epigastriet og under høyre kostalbue, var det normale funn ved organundersøkelse. Blodprøver ved innkomst viste leukocytter 10,3 $\cdot 10^{9} / \mathrm{L}$

(referanseområde 3,9-9,5), CRP 44 mg/L (o-4), alaninaminotransferase (ALAT) 8o U/L (10-70), aspartataminotransferase (ASAT) $48 \mathrm{U} / \mathrm{L}$ (15-45), laktatdehydrogenase (LD) $216 \mathrm{U} / \mathrm{L}$ (105-202) og albumin $36 \mathrm{~g} / \mathrm{L}$ (39-50). Det var normale verdier av hemoglobin, kreatinin, alkalisk fosfatase, totalbilirubin, amylase, lipase og gammaglutamyltransferase (GT). INRverdien ble ikke målt. Urinstiks viste normale funn, og Hemofec-testen var negativ.

Innleggelser grunnet akutte magesmerter hos pasienter med ulcerøs kolitt er ikke uvanlig. Denne mannens ulcerøse kolitt ble oppfattet å være i remisjon, og på bakgrunn av feber og palpasjonsømhet under høyre kostalbue ble akutt kolecystitt vurdert som mulig årsak.

Tentativ diagnose var kolecystitt, og intravenøs behandling med piperacillin/tazobaktam $4 \mathrm{~g} \times 3$ intravenøst ble startet i påvente av ultralyd av lever og galleveier. Ultralyd viste reaksjonsløs lett utspilt galleblære og ellers normale funn. De påfølgende to døgnene følte pasienten seg bedre, men hadde intermitterende feber opp mot $38,6^{\circ} \mathrm{C}$. CRP steg til

$60 \mathrm{mg} / \mathrm{L}(\mathrm{o}-4)$ og leukocyttnivået til $14,4 \cdot 10^{9} / \mathrm{L}(3,9-9,5)$, til tross for bred antibiotikadekning. CT abdomen ble tatt dag 3 og viste upåfallende gastrointestinalkanal. Leveren hadde en ujevn tetthet, tolket som uttrykk for fettinfiltrasjon. Det ble rekvirert utredningsprøver for hepatitt A, B og C, hiv, cytomegalovirus (CMV), Epstein-Barr-virus (EBV) samt antinukleære antistoffer (ANA) og antinøytrofile cytoplasmaautoantistoffer (ANCA).

Siden pasienten hadde vedvarende feber og biokjemisk ikke responderte på antibiotika, $\mathrm{i}$ tillegg til at billedundersøkelse ikke ga grunnlag for å mistenke en kirurgisk tilstand, ble pasienten overflyttet til medisinsk avdeling. Man hadde nå et klinisk bilde med leveraffeksjon og feber med ukjent fokus. Gastroenterolog mistenkte hepatitt eller annen viral infeksjon, eventuelt en autoimmun sykdom som primær skleroserende kolangitt eller autoimmun hepatitt.

Ved overflytning til medisinsk avdeling (dag 3 ) hadde han temperatur på $39,5{ }^{\circ} \mathrm{C}$, slapphet og magesmerter. Han var fortsatt lett palpasjonsøm under høyre kostalbue, ellers var det normal organstatus.

Dag 4 etter innleggelsen anga pasienten smerter bilateralt distalt i begge underekstremiteter. Her så man et makuløst, ikke-avblekbart eksantem, uten ødem. Utslettet var ikke bemerket i innkomst- eller overflytningsnotatet.

På grunnlag av eksantemet ble pasienten samme dag henvist til revmatolog for å avklare om det forelå en immunologisk grunnsykdom. Hos revmatologen anga pasienten smerter $\mathrm{i}$ beina og problemer med gange. Nå kom det fram at utslettet på leggene hadde vart i 5-6 uker. I tillegg hadde han hatt litt hoste uten ekspektorat. Han hadde også hatt lett hodepine og stivhet i nakken de siste ukene, men dette var i ferd med å bedres.

Revmatolog konfererte med hudlege om utslettet og vurderte vaskulitt eller annen revmatologisk sykdom som lite sannsynlig. Det ble anbefalt å supplere utredningen med komplementfaktorer, kryoglobuliner, differensialtelling av leukocytter samt ta urinstiks med mikroskopi og protein/kreatinin-ratio i urin. Rundt dette tidspunktet kom det negativt prøvesvar for ANA, myeloperoksidase-ANCA, proteinase 3-ANCA og kryoglobuliner, og komplementfaktorer var normale.

Dag 6 hadde pasienten vedvarende feber, men stabile inflammasjonsparametre. Man observerte et fall i trombocytter fra $150 \cdot 10^{9} / \mathrm{L}(145-390)$ ved innkomst til $63 \cdot 10^{9} / \mathrm{L}(145-390)$. Piperacillin/tazobaktam ble nå seponert, siden bakteriell infeksjon syntes lite sannsynlig. Hepatitt A-, hepatitt B-, hepatitt C-, hiv-, EBV- og CMV-serologi var negativ. Det ble nå tatt en magnetisk resonanskolangiopankreatografi (MRCP), som viste store områder i leveren med 
diffuse ødemforandringer, dilaterte intrahepatiske galleveier med kaliberveksling samt forstørrede lymfeknuter i leverhilus. Bildet ga mistanke om primær skleroserende kolangitt.

Gallestaseparametrene alkalisk fosfatase, total bilirubin og gammaglutamyltransferase (GT) var fortsatt normale og talte imot kolangitt og klinisk signifikante stenoser i intra/ekstrahepatiske galleveier. På grunn av normal IgG vurderte man også at autoimmun hepatitt var mindre sannsynlig. Man kunne ikke utelukke en klinisk fredelig primær skleroserende kolangitt, eventuelt en overlapp mellom primær skleroserende kolangitt og autoimmun hepatitt. På dette tidspunktet var pasienten oppegående og i relativt god allmenntilstand og fikk dra hjem i permisjon.

Dagen etter ( $\operatorname{dag} 7)$ kom han tilbake på grunn av nyoppståtte, stikkende torakale smerter og tungpustethet, hoste og feber. Ved undersøkelse satt han foroverbøyd og hyperventilerte. Vitale målinger viste puls $114 \mathrm{slag} / \mathrm{min}$, blodtrykk 128/83 mm Hg, respirasjonsfrekvens 32, $\mathrm{SpO}_{2} 96 \%$ og temperatur $39,0^{\circ} \mathrm{C}$. Det var normale auskultasjonsfunn over hjertet og lunger, og utslettet på underekstremitetene var der fortsatt.

Blodgass viste respiratorisk alkalose ( $\mathrm{pH}_{7,49}(7,35-7,45), \mathrm{pCO}_{2} 3,9 \mathrm{kPa}(4,7-6,7), \mathrm{pO}_{2} 7,9 \mathrm{kPa}$ (10,0-14,0), normal laktat). Leukocyttallet hadde steget til 25,3 $10^{9} / \mathrm{L}(3,9-9,5)$.

Differensialtelling, som først nå ble etterbestilt, viste uttalt eosinofili, med eosinofile granulocytter $14,5 \cdot 10^{9} / \mathrm{L}(0,0-0,4)$. Tallet for monocytter var $1,4 \cdot 10^{9} / \mathrm{L}(0,3-0,9)$, lymfocytter $2,2 \cdot 10^{9} / \mathrm{L}(1,3-3,4)$, nøytrofile granulocytter $6,6 \cdot 10^{9} / \mathrm{L}(1,5-5,7)$ og trombocytter $37 \cdot 10^{9} / \mathrm{L}$ (145-390). CRP hadde $ø \mathrm{kt}$ til $118 \mathrm{mg} / \mathrm{L}$ (o-4), LD hadde $ø \mathrm{kt}$ til $315 \mathrm{U} / \mathrm{L}$ (105-205) og D-dimer var $>4,0 \mathrm{mg} / \mathrm{L}(\mathrm{o}-4)$. Fibrinogennivået var forhøyet, 4,9 g/L (2,0-4,0), mens aktivert partiell tromboplastintid (APTT), antitrombin og INR var normale.

Leverprøvene var i bedring. Røntgen thorax viste et infiltrat på venstre side. På mistanke om lungeemboli ble det tatt CT-thorax, som viste flekkvise fortetninger i begge lunger med interstitielt preg, men ingen tegn til lungeemboli.

På grunn av klinisk forverring med eosinofili, trombocytopeni og uavklart infiltrasjon i lever og lunger, ble det reist mistanke om alvorlig hematologisk sykdom. Pasienten ble nå flyttet til hematologisk avdeling. Ut fra laboratoriesvar var det ingen tegn til forbrukskoagulopati som årsak til trombocytopenien.

Blodutstryket var i samsvar med maskinell differensialtelling: 55 \% eosinofile granulocytter og ingen tegn til mikroangiopati. Det ble tatt en benmargsbiopsi. Samtidig laget man et benmargsutstryk (figur 1), som viste lett hypercellulære fragmenter, med $77 \%$ myelopoese og dominans av eosinofile granulocytter, stavkjernede metamyelocytter og myelocytter. Det var ingen blast $\varnothing$ kning.

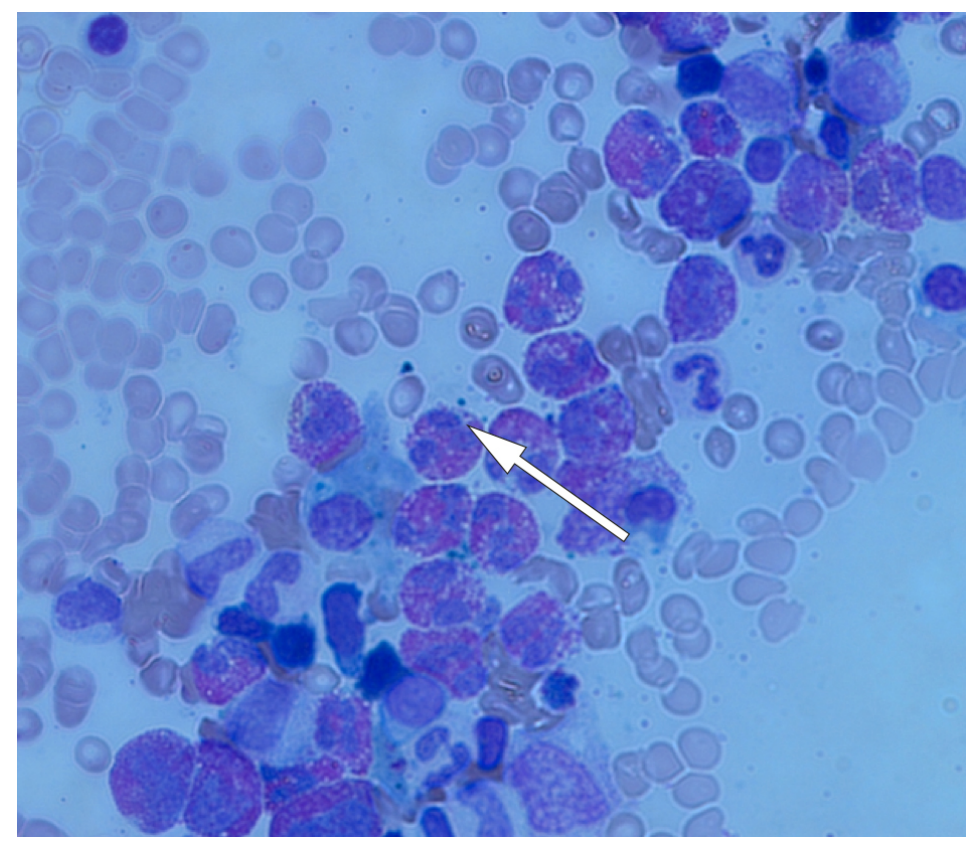


Figur 1 Benmargsaspirat som viser dominans av eosinofile granulocytter. Giemsafarging, 10o× forstørrelse. Pilen peker på en eosinofil granulocytt.

Kombinasjonen negativ serologi, CT-bilder uten glandelsvulst eller klare infeksjonstegn og benmarg uten lymfominfiltrasjon eller blastøkning gjorde at man vurderte infeksjon, lymfom, leukemi og autoimmunitet som lite sannsynlig. Tentativ diagnose var nå alvorlig hypereosinofilt syndrom (HES), med multiorganpåvirkning fra lunger, hud og benmarg.

På bakgrunn av den tentative diagnosen ble det samme kveld igangsatt behandling med høydose peroral prednisolon $1 \mathrm{mg} / \mathrm{kg} \times 1$ daglig. Antikoagulasjonsbehandling ble ikke ansett som nødvendig, da det ikke var tegn til pågående trombosering. Benmargsbiopsi kort tid senere bekreftet funnet fra benmargsutstryket.

Det ble planlagt videre hematologisk utredning med tanke på primære og sekundære hypereosinofile syndromer.

Dagen etter (dag 8) følte pasienten seg i utmerket form. Han hadde ingen dyspné, $\mathrm{SpO}_{2}$ var på $96 \%$ uten $\mathrm{O}_{2}$-tilskudd. Blodprøver viste nå fall i eosinofile granulocytter til $1,8 \cdot 10^{9} / \mathrm{L}$ $(0,0-0,4)$, og leukocytter til 13,5 $10^{9} / \mathrm{L}(3,9-9,5)$. Trombocyttantallet var uendret. CRP hadde steget fra 118 til 18o mg/L (o-4). Protein/kreatinin-ratio i urin ble nå tatt, og var $16 \mathrm{mg} / \mathrm{mmol}$ (o-14).

Det ble dag 9 tatt en hudbiopsi av eksantemet på første tå med tanke på eosinofil granulomatose med polyangiitt (EGPA) som differensialdiagnose til hypereosinofilt syndrom. Utslettene på underekstremitetene var fortsatt til stede, men mindre uttalt.

Ved en eventuell ANCA-negativ eosinofil granulomatose med polyangiitt, som oftere affiserer hjertet enn den ANCA-positive varianten, ble det rekvirert prøver for hjertemarkører. Pro-BNP var 114 ng/L (o-86), og høysensitiv troponin T var 62-50 ng/L (o-14). Det var normale EKG-funn. Forhøyede hjertemarkører ble vurdert som ledd i en multiorganpåvirkning, og det ble ikke foretatt videre hjertemedisinsk utredning.

Pasienten ønsket samme dag (dag 9) ny permisjon grunnet subjektiv bedring, og det var pent fall i CRP til $64 \mathrm{mg} /$ L. Før utreise ble det startet med peroral azitromax $500 \mathrm{mg} \times 1$ i tre dager for å dekke mot en eventuell atypisk pneumoni grunnet de flekksvise fortetningene på røntgen thorax.

Etter to dager (dag 11) kom pasienten tilbake fra permisjonen. Nå hadde han hodepine, nakkesmerte og nummenhet, først i venstre, så i høyre hånd. Pasienten var smertepåvirket. Initialt var Glasgow Coma Scale (GCS)-skåren 15, men like etter innkomst utviklet han et generelt tonisk-klonisk anfall, som ble kupert med diazepam 5 mg intravenøst. Da han våknet til fra krampeanfallet, fant man klinisk slapp parese i høyre overekstremitet, nedsatt kraft i høyre underekstremitet og oppadvendt plantarrefleks på høyre side. CT caput viste hjerneblødning frontalt på venstre side. I løpet av få timer fikk pasienten økende symptomer på høyt intrakranialt trykk, med trang til oppkast og sviktende bevissthet. Han ble intubert og lagt på respirator, med overvåkning på intensivavdelingen. Han var hypertensiv med systolisk trykk 16o-18o mm Hg, det ble gitt infusjon med labetalol $40 \mathrm{mg} / \mathrm{t}$ intravenøst, og han ble omgående overflyttet til universitetssykehus. Der viste CT caput økt hemoragi sekundært til infarktforandringer, og det var mistanke om sinusvenetrombose. Dette ble bekreftet med CT-venografi. Man konkluderte med at han hadde gjennomgått et hemoragisk infarkt sekundært til en trombe i sinus sagittalis.

Pasientens sykehistorie og behandlingsmuligheter ble diskutert med vakthavende nevrokirurg og hematolog. Det ble besluttet å avstå fra antikoagulasjonsbehandling, ettersom det forelå trombocytopeni og massiv blødning med gjennombrudd til ventrikkelsystemet. Mulighet for trombektomi ble vurdert til å være for risikabelt på grunn av trombocytopeni. Man bestemte seg for å seponere sedasjonen og tillate pasienten å våkne.

Dagen etter var pasienten på intensivavdeling og i respirator. Han var komatøs uten spontane bevegelser. I løpet av kort tid den ettermiddagen utviklet han dilaterte, lysstive 
pupiller. En ny CT-undersøkelse viste massivt hjerneødem og herniering. 13 dager etter at pasienten ble innlagt, ble han erklært hjernedød. Organdonasjon var ikke mulig på grunn av uavklart underliggende sykdom.

Ved obduksjon ble det funnet infiltrasjon av eosinofile granulocytter i veggen til sinus sagittalis. Nevropatologisk undersøkelse bekreftet hemoragisk infarkt og sinusvenetrombose. I histologiske snitt tatt fra flere organer fant man vaskulitt med eosinofile granulocytter i karveggen i middelsstore arterier i lever (figur 2) og en arteriegren i meningene. Disse funnene er forenlig med eosinofil granulomatose med polyangiitt som årsak til det hypereosinofile syndromet som ble påvist klinisk.

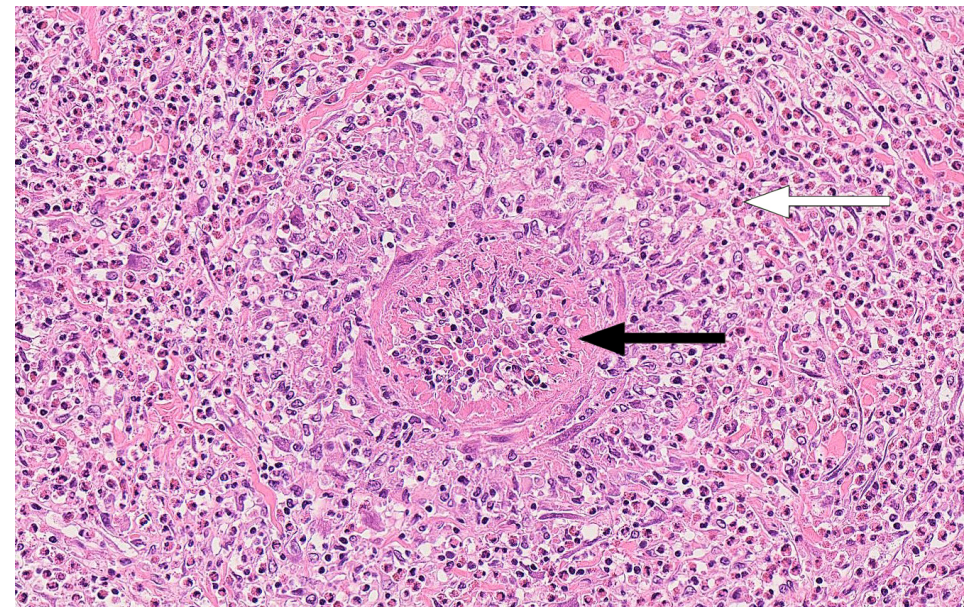

Figur 2 Liten arterie i lever med vaskulitt og rikelig infiltrasjon av eosinofile granulocytter. Hematoksylin-eosin-farging, 20× forstørrelse. Svart pil viser en arterie, hvit pil en eosinofil granulocytt.

\section{Diskusjon}

Eosinofil granulomatose med polyangiitt er en systemisk vaskulitt som før 2012 ble kalt Churg-Strauss' syndrom (1). Tilstanden er karakterisert av allergisk rhinitt, astma og fremtredende eosinofili i perifert blod (2-4). Dens definisjon har vært endret flere ganger siden tilstanden først ble beskrevet i 1951 (2), og i dag foreligger flere klassifikasjonskriterier (ramme 1) $(1,5)(3,4)$. Formålet med disse endringene har vært å øke sensitiviteten og spesifisiteten ved diagnosen og i tillegg muliggjøre raskere diagnostikk, blant annet med bortfall av biopsi som diagnosekrav.

\section{Ramme 1 Eksempler på klassifikasjonskriterier for eosinofil granulomatose med polyangiitt}

American Colleges of Rheumatology (1990) (5)

Kliniske funn med eller uten patologisk materie - diagnose sannsynlig når fire av seks kriterier er til stede:

- Astma

- Eosinofili $>10 \%$

- Nevropati, mononevropati eller polynevropati

- Pulmonale infiltrater

- Paranasal sinusabnormitet

- Ekstravaskulær eosinofil infiltrasjon i biopsifunn 
Chapel Hill Consensus Conference (1994, revidert i 2012) (1)

Patologiske og kliniske funn:

- Eosinofilrik og granulomatøs inflammasjon som involverer luftveiene, og nekrotiserende vaskulitt som affiserer små til middelsstore arterier og er assosiert med astma og eosinofili

Sykdommen er svært sjelden. Insidensen er o,11-2,66 nye tilfeller per 1 million mennesker per år og prevalensen 10,7-14 per 1 million voksne (6). Generelt er eosinofil granulomatose med polyangiitt vurdert til å være en mildere type systemisk vaskulitt med lavere mortalitet enn andre systemiske vaskulitter (7). Med adekvat behandling er femårsoverlevelsen 70-9o \% (8). Involvering av mage-tarm-kanalen eller hjertet er assosiert med et dårlig klinisk utfall (9). Vår pasient hadde en uvanlig presentasjonsform med magesmerter, feber og allmennsymptomer kombinert med raskt progredierende eosinofili og tegn til multiorganpåvirkning.

Tradisjonelle kjennetegn på eosinofil granulomatose med polyangiitt har vært en prodromalfase karakterisert med astma og rhinosinusitt, deretter en eosinofilfase med perifer eosinofili og organaffeksjon og til slutt en vaskulittfase med kliniske manifestasjoner på småkarsvaskulitt (10). Disse fasene er ikke alltid tydelig adskilte.

Ved eosinofil granulomatose med polyangiitt foreligger astma i sykehistorien i 96-100 \% av tilfellene $(9,10)$. I litteraturen er det beskrevet at astma unntaksvis opptrer senere i løpet av vaskulittfasen (9). Vår pasient hadde lettgradig atopisk eksem som barn, men ikke kjent eksem, allergi eller astma i voksen alder. Dag 4 ble pasienten vurdert av revmatolog og hudlege, uten at vaskulitt ble ansett som sannsynlig diagnose. Ved innleggelse var leukocyttallet $10,3 \cdot 10^{9} / \mathrm{L}(3,9-9,5)$. Dette steg relativt raskt til $25,3 \cdot 10^{9} / \mathrm{L}$ en uke etter innleggelse, men differensialtellingen som viste uttalt eosinofili, ble dessverre først tatt dag 7. Først da ble det mistenkt hypereosinofilt syndrom.

Eosinofil granulomatose med polyangiitt har fellestrekk med hypereosinofilt syndrom (tabell 1)(6). Vi tolket pasientens tilstand først som hypereosinofilt syndrom, og startet behandling for dette. Begge tilstander vil i initialfasen behandles med høydose kortikosteroider. Selv om hypereosinofili ved begge tilstander er assosiert med $ø \mathrm{kt}$ risiko for tromboembolisme, er effekten av antikoagulasjonsbehandling hos disse pasientene omdiskutert. Uten tegn til åpenbar trombose anbefales det ikke som primærprofylakse (11).

\section{Tabell 1}

Sammenligning av kliniske manifestasjoner ved hypereosinofilt syndrom og eosinofil granulomatose med polyangiitt(6).

\begin{tabular}{|lll|}
\hline Kliniske manifestasjoner & $\begin{array}{l}\text { Hypereosinofilt } \\
\text { syndrom }\end{array}$ & $\begin{array}{l}\text { Eosinofil granulomatose } \\
\text { med polyangiitt }\end{array}$ \\
\hline Hjerteaffeksjon & $\begin{array}{l}\text { Endokardial fibrose, } \\
\text { restriktiv } \\
\text { kardiomyopati }\end{array}$ & $\begin{array}{l}\text { Affeksjon av perikard og } \\
\text { myokard, småkarsvaskulitt }\end{array}$ \\
\hline Astma & Sjelden & Nesten alltid til stede \\
\hline Sinusitt & Sjelden & Vanlig \\
\hline Affeksjon av perifere nerver & Sjelden & Vanlig \\
\hline Affeksjon av hud & Urtikaria & Purpura, urtikaria \\
\hline Økt senkning & Sjelden & Vanlig \\
\hline Økt IgE & Sjelden & Vanlig \\
\hline Biopsiverifisert vaskulitt & Fraværende & $\begin{array}{l}\text { Til stede (spesielt i sen } \\
\text { fase) }\end{array}$ \\
\hline
\end{tabular}




\begin{tabular}{|lcc|}
\hline Kliniske manifestasjoner & $\begin{array}{l}\text { Hypereosinofilt } \\
\text { syndrom }\end{array}$ & $\begin{array}{l}\text { Eosinofil granulomatose } \\
\text { med polyangiitt }\end{array}$ \\
\hline $\begin{array}{l}\text { Antinøytrofile } \\
\text { cytoplasmaautoantistoffer }\end{array}$ & Fraværende & $\begin{array}{l}\text { Til stede hos ca. } 40 \% \\
\text { pasienter }\end{array}$ \\
\hline
\end{tabular}

Pasienten fikk etter hvert lungeinfiltrater, som er et svært vanlig funn ved eosinofil granulomatose med polyangiitt. I tillegg hadde han et vaskulittsuspekt utslett, og man kan i etterkant spørre seg om hans gangvansker var et uttrykk for polynevropati. Nervesystemet er ofte affisert ved eosinofil granulomatose med polyangiitt, og American College of Rheumatology har dette blant klassifikasjonskriteriene - da som perifer nevropati (ramme 1). Sentral affeksjon er langt sjeldnere og er sparsomt beskrevet i litteraturen. Når det forekommer, er det beskrevet som cerebrale infarkter og hjerneblødninger $(9,12,13)$.

Antinøytrofile cytoplasmaautoantistoffer (ANCA) påvises hos 40-6o \% av pasientene, og eosinofil granulomatose med polyangiitt er klassifisert blant de ANCA-assosierte vaskulittene $(14,15)$. ANCA-negativitet kan være assosiert med $ø$ kt hjerteaffeksjon, gastrointestinal involvering, pulmonale infiltrater, livstruende hendelser og død (16), slik som hos vår pasient.

Selv om man startet med kortikosteroider, som er hjørnesteinsbehandlingen for eosinofil granulomatose med polyangiitt $(9,14)$, sto ikke pasientens liv til å redde. Tidligere differensialtelling av leukocytter kunne sannsynligvis bidratt til tidligere oppstart av behandling. Hudbiopsien tatt dag 9 viste superfisiell perivaskulær lymfocyttær betennelse, som er et uspesifikt funn. Biopsien ble imidlertid tatt to døgn etter oppstart av steroider, og det er usikkert om hudbiopsi på et tidligere tidspunkt hadde gitt en tidligere diagnose.

Pasienten hadde flere dårlige prognostiske tegn, som involvering av gastrointestinalkanalen (lever), myokard og sentralnervesystemet. Da pasienten hadde en utmerket effekt både klinisk og biokjemisk 1-2 døgn etter oppstart av prednisolon, forelå det ingen åpenbare motforestillinger mot at han kunne dra i permisjon.

Sinusvenetrombose og blødning oppsto etter at antall eosinofile granulocytter var normalisert, og det er således usikkert om utfallet hadde blitt noe annerledes dersom diagnosen hadde blitt stilt tidligere.

\section{LITTERATUR:}

1. Jennette JC, Falk RJ, Bacon PA et al. 2012 revised international Chapel Hill consensus conference nomenclature of vasculitedes. Arthritis Rheum 2013; 65:1-11. [PubMed][CrossRef]

2. Churg J, Strauss L. Allergic granulomatosis, allergic angiitis, and periarteritis nodosa. Am J Pathol 1951; 27: 277-301. [PubMed]

3. Noth I, Strek ME, Leff AR. Churg-Strauss syndrome. Lancet 2003; 361: 587-94. [PubMed][CrossRef]

4. Skoner DP. Allergic rhinitis: definition, epidemiology, pathophysiology, detection, and diagnosis. J Allergy Clin Immunol 2001; 108: S2-8. [PubMed][CrossRef]

5. Masi AT, Hunder GG, Lie JT et al. The American College of Rheumatology 1990 criteria for the classification of Churg-Strauss syndrome (allergic granulomatosis and angiitis). Arthritis Rheum 1990; 33: 1094-10o. [PubMed][CrossRef]

6. Baldini C, Talarico R, Della Rossa A et al. Clinical manifestations and treatment of Churg-Strauss syndrome. Rheum Dis Clin North Am 2010;36: 527-43. [PubMed][CrossRef]

7. Mukhtyar C, Flossmann O, Hellmich B et al. Outcomes from studies of antineutrophil cytoplasm antibody associated vasculitis: a systematic review by the European League Against Rheumatism systemic vasculitis task force. Ann Rheum Dis 2008; 67: 1004-10. [PubMed][CrossRef]

8. Saku A, Furuta S, Hiraguri M et al. Longterm outcomes of 188 Japanese Patients with eosinophilic granulomatosis with polyangiitis. J Rheumatol 2018; 45: 1159-66. [PubMed][CrossRef]

9. Guillevin L, Cohen P, Gayraud M et al. Churg-Strauss syndrome. Clinical study and long-term followup of 96 patients. Medicine (Baltimore) 1999; 78: 26-37. [PubMed][CrossRef] 
10. Lanham JG, Elkon KB, Pusey CD et al. Systemic vasculitis with asthma and eosinophilia: a clinical approach to the Churg-Strauss syndrome. Medicine (Baltimore) 1984; 63: 65-81. [PubMed][CrossRef]

11. Ogbogu PU, Rosing DR, Horne MK. Cardiovascular manifestations of hypereosinophilic syndromes. Immunol Allergy Clin North Am 2007; 27: 457-75. [PubMed][CrossRef]

12. André R, Cottin V, Saraux JL et al. Central nervous system involvement in eosinophilic granulomatosis with polyangiitis (Churg-Strauss): Report of 26 patients and review of the literature. Autoimmun Rev 2017; 16: 963-9. [PubMed][CrossRef]

13. Sabio JM, Rivero-Rodriguez M, Vargas-Hitos JA. Demographic and clinical characteristics associated with central nervous system hemorrhage in patients with eosinophilic granulomatosis with polyangiitis: A case report and review of the literature. J Rheumatol 2017; 44:1413-5. [PubMed][CrossRef]

14. Conron M, Beynon HL. Churg-Strauss syndrome. Thorax 2000; 55: 870-7. [PubMed][CrossRef]

15. Pagnoux C, Guillevin L. Churg-Strauss syndrome: evidence for disease subtypes? Curr Opin Rheumatol 2010; 22: 21-8. [PubMed][CrossRef]

16. Healy B, Bibby S, Steele R et al. Antineutrophil cytoplasmic autoantibodies and myeloperoxidase autoantibodies in clinical expression of Churg-Strauss syndrome. J Allergy Clin Immunol 2013; 131: 571-6.e1, 6. [PubMed][CrossRef]

Publisert: 14. desember 2020. Tidsskr Nor Legeforen. DOI: 10.4045/tidsskr.20.0150

Mottatt 26.2.2020, første revisjon innsendt 5.6.2020, godkjent 18.9.2020.

(C) Tidsskrift for Den norske legeforening 2020. Lastet ned fra tidsskriftet.no 